\title{
Effect of insect growth regulators combined with nucleopolyhedrovirus on certain biological and histological aspects of Spodopera littoralis.
}

\author{
A. E. Abdel-Aal ${ }^{2}$; A. Thabit ${ }^{2}$; S. El Salamaouny ${ }^{1}$; M.A.K. El-Sheikh ${ }^{1}$ \\ and S. Elnagar ${ }^{1}$ \\ 1-Department of Economic Entomology and Pesticides, Faculty of Agriculture,Cairo \\ University \\ 2- Plant Protection Research Institute, Agricultural Research Center, Dokki, Giza, Egypt.
}

\section{ABSTRACT}

Five insect growth regulators (IGR's) were tested for increasing the susceptibility of the cotton leaf worm, Spodoptera littoralis (Boisd.) (Lepidoptera: Noctuidae) to its homologous nucleopolyhedrovirus (SpliMNPV). S. littoralis MNPV was tested alone or in combination with IGR's at $\mathrm{LC}_{10}$ level against the $2^{\text {nd }}$ instar larvae of the pest. An increased viral infection rate was detected in the mixture treatment in the case of using Chlorfluazuron, Flufenoxuron, Triflumuron, Hexaflumuron or Teflubenzuron at $10 \%$. The $\mathrm{LC}_{50}$ value of the virus alone treatment $1 \times 10^{7}$ PIB's was reduced to $4.3 \times 10^{6}, 9.9 \times 10^{4}, 4.9 \times 10^{4}, 3.1 \times 10^{5}$ and $1.69 \times 10^{6}$ PIB's, $^{2}$ with the tested five IGR's, respectively. It was observed that Flufenoxuron and Triflumuron mixtures slightly prolongated larval duration compared either untreated control or IGR's alone treatments. The highest rate of decrease in the pupation percentage $(47 \%)$ was recorded in case of Triflumuron mixed with SpliMNPV followed by Flufenoxuron and Chlrofluazuron mixes. On the other hand there is no significance difference in pupal weight for all treatments. Changes Adult longevity was increased for all treatments compared to untreated control. Addition Flufenxuron $\left(\mathrm{LC}_{10}\right)$ to SpliMNPV $\left(\mathrm{LC}_{50}\right)$ showed histopathological effects to mid gut e.g. loss of the compact appearance of the muscularis layer, vaculation and exfoliation of the columnar cells.

Keywords: Insect growth regulators (IGR's), Nucleopolyhedrovirus (NPV), Spodoptera littoralis, biological and histological aspects.

\section{INTRODUCTION}

The extensive use of insecticides to control Spodoptera littoralis (Boisd.) larvae has led to its resistance to various classes of insecticides (Tabashink et al., 1987), residual toxicity and environmental pollution (Frank et al., 1990) and negative effects on non-target organisms (Franz, 1974). Numerous studies have been undertaken for unconventional control agents owing to the hazards of conventional pesticides. Among such agents are the baculoviruses. Several efforts have been made to enhance the baculoviruses efficiency by increasing insect host susceptibility to virus by using certain additives such as Fluorescent brighteners (El-Salamouny, 2004). Flufenoxuron (IGR) promoted infection of the silkworm Bombyx mori $5^{\text {th }}$ instar larvae by $B$. mori nucleopolyhedrovirus (BmNPV) which could be due to interference with chitin synthesis of peritrophic membrane (Arakawa, 2002). Therefore, the present study is undertaken to further investigate the combined effect of the mixture of IGR and NPV. Certain IGR's were evaluated as additives to increase the susceptibility of $S$. littoralis larvae to its homologous nucleopolyhedrovirus (SpliMNPV). 


\section{MATERIALS AND METHODS}

\section{Materials:-}

Used compound: I-Nucleopolyhedrovirus (SpliMNPV): The Egyptian isolate of Spodoptera littoralis multiple embedded nucleopolyhedrovirus (SpliMNPV) was used (Abul Nasr, 1956). The different concentrations of polyhedra inclusion bodies (PIB's) were prepared in distilled water and number of PIB's was determined by haemocytometer.

II- Insect growth regulators (IGR's), (Chitin synthesis inhibitors): Five insect growth regulators were evaluated (Chlorfluazuron (IKI-7899, 10\% EC), Flufenoxuron (10\% DC), Hexaflumuron (Consult, 10\% EC), Teflubenzuron (15\% EC), and Triflumuron $(48 \%$ SC) and their concentrations were prepared in distilled water.

\section{Methods:-}

\section{1- Bioassay and follow up:}

The cotton leafworm, Spodoptera littoralis (Boisd.) (Lepidoptera: Noctuidae) was maintained at the "Insect Virology Unit", Department of Economic Entomology and Pesticides, Faculty of Agriculture, Cairo University, under laboratory conditions of $25 \pm 2{ }^{\circ} \mathrm{C}$ and $60 \pm 5 \% \mathrm{RH}$. The standard test insect used in the bioassay of all experiments was three to four days old $2^{\text {nd }}$ instar larvae. Newly moulted $2^{\text {nd }}$ instar larvae were treated with a mixture of the $\mathrm{LC}_{10}$ of the tested (IGR's) mixed with the $\mathrm{LC}_{50}$ of SpliMNPV. Treated larvae were examined daily to determine the post treatment effects on those insects survived the treatments, (e.g., the larval duration, pupation \%, pupal weight and adult emergence \%). These parameters were compared with the untreated control larvae.

\section{2- Histopathological study:}

The Histopathological study was undertaken on the mid gut of late $6^{\text {th }}$ larval instars treatments as $2^{\text {nd }}$ instars with the mixture of IGR + SpliMNPV. The tested tissues were fixed in aqueous Bouin's solution for $24 \mathrm{hr}$. The normal paraffin wax embedding procedure was followed. The sections were cut $6 \mu$ thick and stained with heamatoxylin and eosin for microscopic examination. Control sections of non-treated larvae were also carried out.

\section{3-Statistical analysis:}

Statistical analysis (ANOVA) of the obtained data was performed using COSTAT program, which runs under WIN. Also, the difference between means was conducted by using Duncan's multiple range test (Duncan, 1955). Mortalityconcentration response was estimated according to Finney (1971).

\section{RESULTS AND DISCUSSION}

\section{Effect of IGR's at $\mathrm{LC}_{10}$ concentration, mixed with SpliMNPV at $\mathrm{LC}_{50}$ value.}

The results presented in table 1 indicate that mixing SpliMNPV with IGR reduced the $\mathrm{LC}_{50}$ of SpliMNPV from $1 \times 10^{7} \mathrm{BIP} / \mathrm{ml}$ to $4.3 \times 10^{6}, 9.9 \times 10^{4}, 4.9 \times 10^{4}$, $3.1 \times 10^{5}, 1.69 \times 10^{6}$, when mixed with Chlorfluazuron, Flufenoxuron, Triflumuron, Hexaflumuron, Teflubenzron, respectively.

The use of $\mathrm{IGR}_{\mathrm{s}}$ is based on its effect on the chitin synthesis process. The obtained result that the insect growth regulator "Flufenoxuron" proved to be a synergistic additive to viral pesticides of Spodoptera littoralis is similar to that found in case of the silkworm, Bombyx mori by Arakawa (2002). However, the rate of enhance-ment of 204.08 fold with IGR additive is much less compared to 2000 fold in case of the silkworm. This could be attributed to differences among insects in the rate 
of interference with chitin synthesis of peritrophic membrane (PM). This explanation agrees with the theory of enhancement of baculovirus by protease in the enhancing protein as indicated by Lepore et al. (1996). Increasing the rate of mortality which is reflected by decreasing the $\mathrm{LC}_{50}$ value of SpliMNPV in present results could be due to facilitating the virus invasion through the midgut epithelial cells by IGR's.

Table 1: Viral mortality among Spodoptera littoralis $2^{\text {nd }}$ instar larvae treated with LC $_{10}$ of IGR's mixed with different concentrations of SpliMNPV.

\begin{tabular}{|c|c|c|c|c|c|c|}
\hline \multirow{2}{*}{$\begin{array}{l}\text { Tested IGR additive at } \\
\text { LC }_{10} \text { concentration }\end{array}$} & \multicolumn{4}{|c|}{$\begin{array}{l}\text { Larval mortality \% at the indicated concentration } \\
\text { f (SpliMNPV) mixed with IGR's additive at LC } \mathrm{C}_{10}\end{array}$} & \multirow{2}{*}{$\begin{array}{l}\text { Virus } \mathrm{LC}_{50} \text { in } \\
\text { the mixture }\end{array}$} & \multirow{2}{*}{ Fold } \\
\hline & $\begin{array}{l}10^{7} \\
\end{array}$ & $10^{6}$ & $10^{5}$ & $4.3 \times 10^{4}$ & & \\
\hline Chlrofluazuron & $\begin{array}{l}57.1 \\
(49)^{\circ}\end{array}$ & $\begin{array}{l}41.6 \\
(48)\end{array}$ & $\begin{array}{l}6.00 \\
(50)\end{array}$ & $\begin{array}{l}6.25 \\
(48)\end{array}$ & $4.30 \times 10^{6}$ & 2.3 \\
\hline Flufenoxuron & $\begin{array}{l}72.0 \\
(50)\end{array}$ & $\begin{array}{l}48.9 \\
(49)\end{array}$ & $\begin{array}{l}16.0 \\
(50)\end{array}$ & $\begin{array}{l}2.00 \\
(50)\end{array}$ & $9.90 \times 10^{4}$ & 101 \\
\hline Triflumuron & $\begin{array}{c}75.57 \\
(49) \\
\end{array}$ & $\begin{array}{l}64.0 \\
(50)\end{array}$ & $\begin{array}{l}62.0 \\
(50)\end{array}$ & $\begin{array}{l}36.0 \\
(50) \\
\end{array}$ & $4.90 \times 10^{4}$ & 204.08 \\
\hline Hexaflumron & $\begin{array}{l}84.0 \\
(50)\end{array}$ & $\begin{array}{l}78.0 \\
(50)\end{array}$ & $\begin{array}{l}20.0 \\
(50)\end{array}$ & $\begin{array}{l}18.0 \\
(50)\end{array}$ & $3.10 \times 10^{5}$ & 32.25 \\
\hline Teflubenzuron & $\begin{array}{l}68.0 \\
(50) \\
\end{array}$ & $\begin{array}{l}46.9 \\
(49) \\
\end{array}$ & $\begin{array}{l}16.0 \\
(50)\end{array}$ & $\begin{array}{l}18.0 \\
(50)\end{array}$ & $1.69 \times 10^{6}$ & 6.25 \\
\hline None & $\begin{array}{l}51.1 \\
(47)\end{array}$ & $\begin{array}{l}29.7 \\
(49)\end{array}$ & $\begin{array}{l}18.3 \\
(50)\end{array}$ & $\begin{array}{l}4.40 \\
(49)\end{array}$ & $1.07 \times 10^{7}$ & - \\
\hline
\end{tabular}

* Mortality is due to virus infection, ${ }^{*}$ Total tested larvae.

\section{Effect of either single or combined treatments of tested IGR's and SpliMNPV (PIB's), on some biological aspects of the host.}

The mean larval duration in Table (2) recorded highest value for both Flufenoxuron, Triflumuron alone (27.3 \pm 0.17 and $27 \pm 0.29$ days) compared to $(25 \pm$ 0.58 and $25.5 \pm 0.16$ ) days for the mixture. The virus alone treatment recorded $25.5 \pm$ 0.12 days compared to the untreated control ( $24.5 \pm 0.29$ days). The larval weight demonstrated in Table (2) recorded insignificant differences between treatments and the untreated control.

Table 2: Rate of pupation, adult emergence and adult longevity of S. littoralis treatment as $2^{\text {nd }}$ instar larvae with either insect growth regulators; SpliMNPV or their mixture.

\begin{tabular}{|c|c|c|c|c|}
\hline Tested treatment & Larval duration days) & Pupal weight (gm) & $\begin{array}{c}\text { Pupation } \\
\%\end{array}$ & $\begin{array}{c}\text { Adult } \\
\text { emergence \% }\end{array}$ \\
\hline Control & $24.5^{\mathrm{c}} \pm 0.29$ & $0.33 \pm 0.02$ & 100 & 100 \\
\hline Virus $\left(10^{7}\right)$ alone & $25.5^{\mathrm{b}} \pm 0.12$ & $0.30 \pm 0.03$ & 100 & 100 \\
\hline Teflubenzuron alone & $25.5^{\mathrm{b}} \pm 0.23$ & $0.33 \pm 0.01$ & 100 & 87 \\
\hline Teflubenzuron+SpliMNPV & $25^{\mathrm{bc}} \pm 0.06$ & $0.34 \pm 0.02$ & 90 & 97 \\
\hline Flufenoxuron alone & $27.3^{\mathrm{a}} \pm 0.17$ & $0.29 \pm 0.02$ & 100 & 73 \\
\hline Flufenoxuron+ SpliMNPV & $25.0^{\mathrm{bc}} \pm 0.58$ & $0.33 \pm 0.02$ & 80 & 88 \\
\hline Triflumuron alone & $27.0^{\mathrm{a}} \pm 0.29$ & $0.34 \pm 0.01$ & 100 & 47 \\
\hline Triflumuron+ SpliMNPV & $25.5^{\mathrm{b}} \pm 0.16$ & $0.35 \pm 0.03$ & 47 & 100 \\
\hline Chlrofluazuron alone & $25.5^{\mathrm{b}} \pm 0.34$ & $0.30 \pm 0.01$ & 100 & 100 \\
\hline Chlrofluazuron+SpliMNPV & $25.3^{\mathrm{bc}} \pm 0.05$ & $0.33 \pm 0.01$ & 80 & 100 \\
\hline F value & $10.421^{* * *}$ & $1.064^{\text {ns }}$ & & \\
\hline L.S.D. & 0.801 & - & & \\
\hline
\end{tabular}

Means with the same letter are not significantly different $(\mathrm{p}<0.05)$.

Obtained results agree with Abd-El Wahed et al., (2010) as SpliMNPV reduced larval duration as well as adult emergence of $S$. littoralis . Results about the reduction in pupation due to viral infection go in line with those obtained by Dutton et al. (2003). Also, the data in Table (2) demonstrate that the pupal weight recorded 
insignificant result for either SpliMNPV alone, IGR's alone or the mixture of them .The data presented in Table (2) demonstrate that, the highest reduction in the pupation percentage $(47 \%)$ was recorded in case of Triflumuron mixed with SpliMNPV followed by Flufenoxuron \& Chlrofluazuron $\left(\mathrm{LC}_{10}\right)$ mixed with SpliMNPV $\left(\mathrm{LC}_{50}\right)(80 \%)$ compared to $100 \%$ in case of both the untreated control and IGR's alone. The adult emergence (Table 3) was remarkably reduced in case of Triflumuron alone (47\%) followed by Flufenoxuron alone (73\%), Teflubenzuron alone $(87 \%)$, Flufenoxuron + SpliMNPV (88\%) and Teflubenzuron+ SpliMNPV (97\%), while it recorded $100 \%$ for the other treatments.

\section{Histpathological effect on mid gut of treated larvae:}

The histological structure of mid gut in normal larvae (fig.1) is well documented (Chapman, 1988). The light microscope examination of S. littoralis treated with $\mathrm{LC}_{50}$ SpliMNPV alone in (Fig.2) Shows vacuolization of the columnar cells. The peritrophic membrane was considerably deteriorated. On the other hand, the larvae treated with the IGR Flufenxuron alone (Fig 3) Show exfoliation and vacuolization of the midgut epithelium. The peritrophic membrane was completely disrupted. However, treatment with the mixture SpliMNPV $\left(\mathrm{LC}_{50}\right)+$ Flufenxuron $\left(\mathrm{LC}_{10}\right)$ (Fig. 4) Shows a loss of the compact appearance of the muscular layer, vacuolation and exfoliation of the columnar cells. Many of the histological alterations reported in the present study for the midgut of $S$. littoralis larvae treated with IGR are similar to those reported by Thabit et al. (2010). Also, Federici (1993) found that the ingestion of toxicant by the insects releases a toxic peptide which binds to sites on the microvillar membrane of the mid gut causing cytolysis, which leads to paralysis and subsequently death of the insect.

\section{REFERENCES}

Abd-El Wahed S., M. F. Mariy,A. E. Abdel-Aal And M. M. Abdel-Aziz. (2011). The Effect of certain bio-insecticided on some biological ,biochemical and histological aspects of the Egyptian cotton leaf worm Spodoptera littoralis (Lepidoptera: Noctuidae). Egypt J. Agric .Res ., 89(2),

Arakawa T. (2002). Promotion of nucleopolyhedrovirus infection in larvae of the silkworm, Bombyx mori (Lepidoptera: Bombycidae) by flufenoxuron. Appl. Entomol. Zool. 37 (3): 393-397.

Chapman, R. F. (1988). The insects structure and function. $3^{\text {rd }}$ edition. English Language Book Society/ Edward Arnold. 50-52 pp.

Duncan, D. B. (1955). Multiple range and multiple F-test. Boimetrics, 11 (1): 1- 24.

Dutton, A.; Klein, H.; Romeis, J. and Bigler, F. (2003). Pre-mediated effects of Bacillus thuringiensis spray on the predator Chrysoperla carnea in maize. Biol. Control. 26(2): 209-215.

El-Salamouny, S. (2004). Effect of certain optical brightener on the susceptibility of Spodoptera littoralis (Boisduval) (Lepidoptera: Noctuidae) to a baculovirus: effect on some biological aspects. J. Agric. Sci. Mansoura Univ., 29(5): 28792892.

Federici, B. A. (1993). insecticidal bacterial proteins identify the midgut epithelium as a source of novel target sites for insect control. Arch. Insect Biochem. Physiol., 22: 357-371.

Finney, D.J. (1971). Probit Analysis: a Statistical Treatment of the Sigmoid Response Curve. P. 33. Cambridge Univ. Press, London. 
Frank, R.; Braun, H. E.; Ripley, B. D. and Clegy, B. S. (1990). Contamination of rural ponds with pesticides, 1971-1985. Ontario, Canada. Bull. Environ. Contamin. Toxicol. 13: 771-817.

Franz, J. M. (1974). Testing of side effects of pesticides on beneficial arthropods in laboratory: a review. Z. Pfl. Krankh. Fl. Schutz, 18: 141-174.

Lepore, L. S.; Roelvink P. R. and Granados R. R. (1996). Enhancin, the granulosis virus protein that facilitates nucleopolyhedrovirus (NPV) infections, is a metalloprotease. J. Invertebr. Pathol. 68 (2): 131-140.

Tabashink, B. E.; Cushing, N. L. and Johnson, M. W. (1987). Diamond back moth (Lepidoptera: Plutellidae) resistance to insecticides in Hawaii: Intra-island variation and cross resistance. J. Econ. Entomol., 80: 1091-1099.

Thabit, A.; S. El Salamouny; A.E. Abdel-Aal; M.A.K. El-Sheikh and S. Elnagar.(2010) Enhancement of Spodoptera littoralis suscebtability to nucleopolyhedrovirus (splimnpv) combined with insect growth regulators (igrs). bull. fac. agric., cairouniv., 61:92-96. 


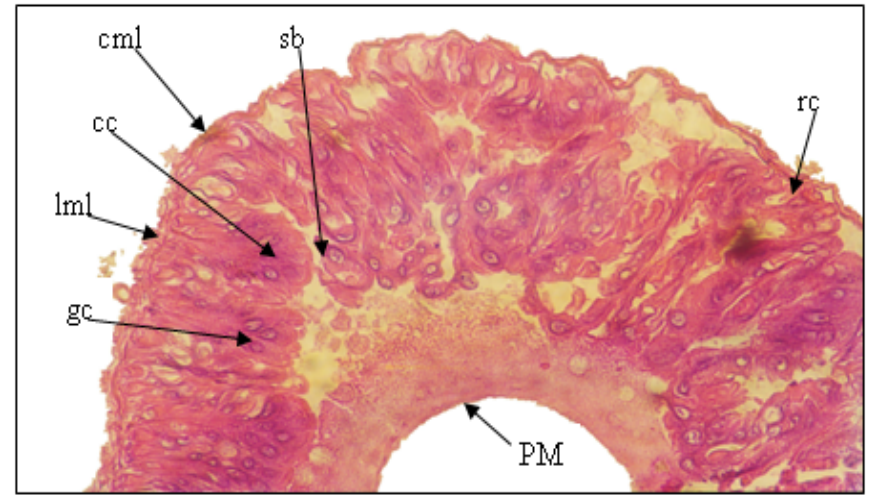

Fig. 1: Photomicrograph of longitudinal section in the mid gut of untreated late $6^{\text {th }}$ instar larvae of $S$. littoralis (X400). cc: Columnar cell. pm: Peritrophic membrane. cml: Circular muscle layer. rc: Regenerative cell. gc: Goblet cell. sb: Striated boarder iml: Longitudinal muscle layer.

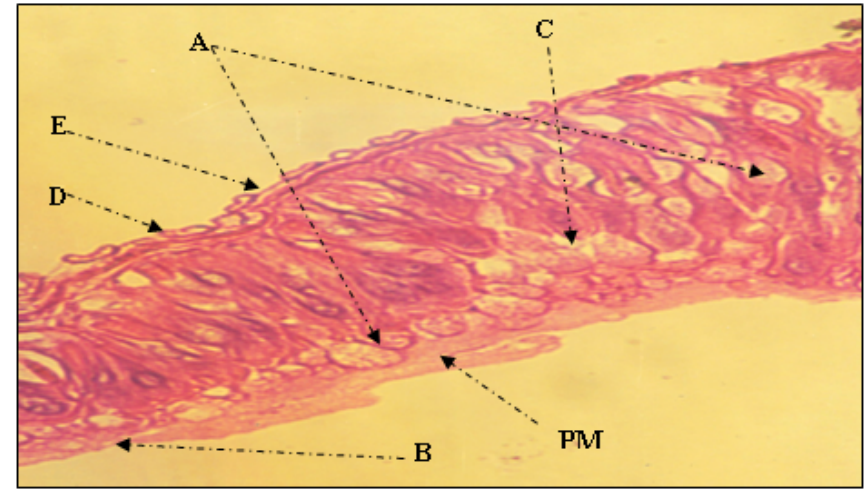

Fig. 2: Photomicrograph of longitudinal section in the mid gut of late $6^{\text {th }}$ larval instar of $S$. littoralis treated as $2^{\text {nd }}$ instar larvae with $\mathrm{LC}_{50}$ of SpliMNPV(X400). A: Vaculization of columnar cells. B: Shrinking of the peritrophic membrane. D: longtuidinal muscle layer L.M.L. C: Loss of striated border of epithelial cell. E: circular muscle layer C.M.L.

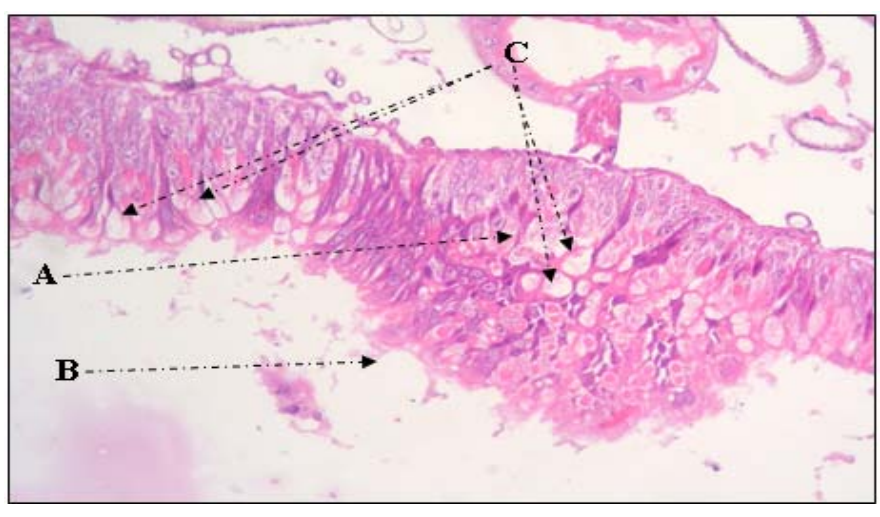

Fig. 3: Photomicrograph of longitudinal section in the mid gut of late $6^{\text {th }}$ larval instar of $S$. littoralis treated with $\mathrm{LC}_{50}$ of Flufenoxuron as $2^{\text {nd }}$ instar larvae (X400). A: The colomnar cell lost its compact appearance. B: Completely disrupted peritrophic membrane. C: Vaculization of midgut epithelial.

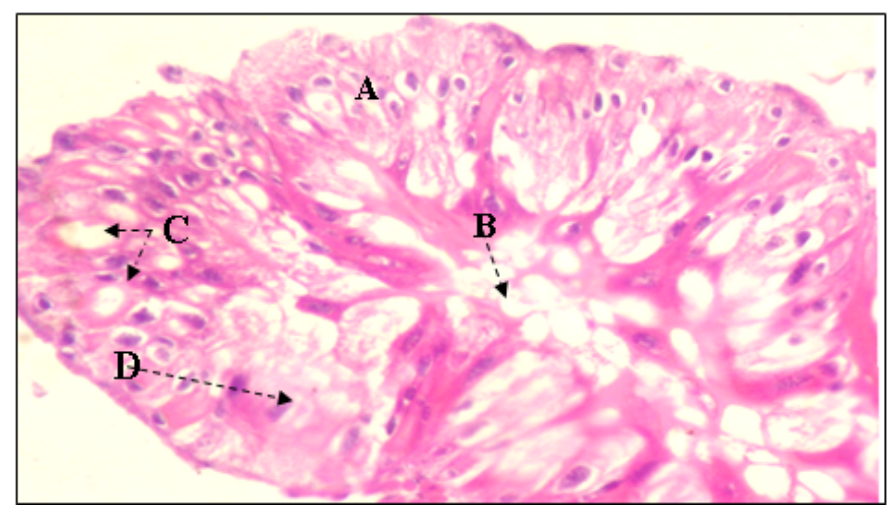

Fig. 4: Photomicrograph of longitudinal section in the mid gut of late $6^{\text {th }}$ larval instar of $S$. littoralis treated as $2^{\text {nd }}$ instar larvae with the mixture $\left(\mathrm{LC}_{50}\right.$ of NPV and $\mathrm{LC}_{10}$ of IGR) (X400). A: Loss of the compact appearance of muscular layer. B: Lumen with punched epithelial cells. C: Vaculation. D: Exoflation the culamar epithili layer. 


\section{ARABIC SUMMARY}

تأثير منظمات النمو الحشريه مخلوطا مع المعامله بالفيروس علي بعض الجوانب البيولوجيه والهستولوجيه

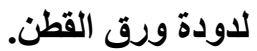

عزيزة السيد عبد العال1 و أمال ثابت ثابت1 و سعيد السلامونى2 و محمد عبد القادر2 صو صلاح النجار 2

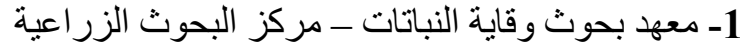

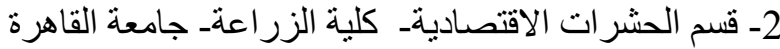

تم اختبار خمسه من منظمات النمو الحشريه بهدف زيادة حساسيه دودة ورق القطن اتجاه

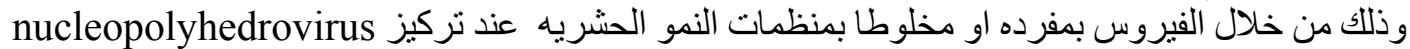

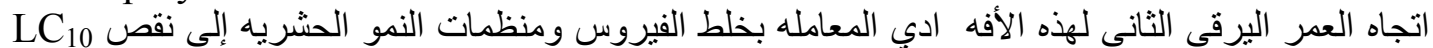

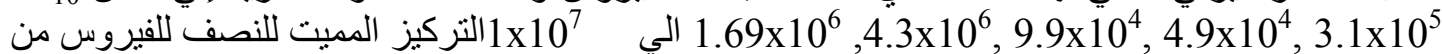

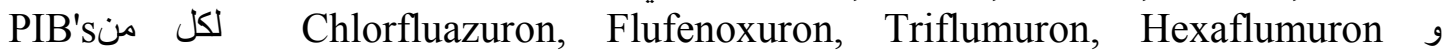

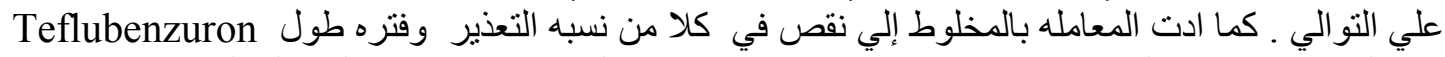

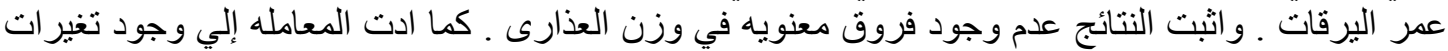
هستولوجيه في المعي الأوسط للحشرة 